\title{
A novel PARD3B-NUTM1 fusion in an aggressive primary CNS embryonal tumor in a young adult
}

\author{
Kyungmin Ko ${ }^{1}$, Takashi Kitani ${ }^{2,3}$, Brent T. Harris ${ }^{1,2,3}$, Amjad N. Anaizi ${ }^{4}$, David Solomon ${ }^{5}$, Arie Perry ${ }^{5}$, \\ Jeffrey Toretsky ${ }^{2}$ and Metin Ozdemirli ${ }^{*}$ (D)
}

Keywords: CNS embryonal tumor, NUT carcinoma, NUTM1, Next-generation sequencing

\section{Main text}

We report a novel PARD3B-NUTM1 gene fusion in a primary embryonal tumor of the brain which had a very aggressive course. A 29-year-old female presented with worsening headache of three-weeks duration. CT and MRI showed a hemorrhagic mass involving the right inferior frontal lobe and temporal lobe (Fig. $1 \mathrm{a}, \mathrm{b}$ ). The tumor was well-demarcated. It was surgically removed with no gross residual tumor. MRI on post-operative day 27 showed recurrence and additional tumor in the prepontine region and between cerebellar tonsils. Chemotherapy with vincristine, cisplatin, and cyclophosphamide was initiated and staged re-excisions were performed, but the patient expired due to intraventricular hemorrhage on post-operative day 34. A comprehensive postmortem examination revealed no residual viable tumor in the brain or any other extracranial tumor.

Microscopic sections showed a relatively wellcircumscribed, moderately cellular neoplasm. The tumor had a variegated histology with foci showing primitive, spindle cells in a myxoid to fibrillar background, foci showing small epithelioid cells with clear cytoplasm around thin-walled vessels, and foci of microvascular proliferation and necrosis (Fig. $1 \mathrm{c}$-e). There was microscopic infiltration of adjacent brain parenchyma by single tumor cells and reactive gliosis. Mitoses were

\footnotetext{
* Correspondence: mo7@gunet.georgetown.edu

'Department of Pathology and Laboratory Medicine, Georgetown University Hospital, 3900 Reservoir Rd NW, Washington, DC 20007, USA

Full list of author information is available at the end of the article
}

frequent. No well-differentiated islands of squamous epithelium characteristic of NUT midline carcinoma were observed. By immunohistochemistry (Figs. $1 \mathrm{f}-\mathrm{k}$ ), there was diffuse CD56 expression, patchy dot-like and strong membranous expression of CD99, focal neurofilament expression and GFAP was positive in a small subset of epithelioid tumor cells. Synaptophysin was positive in single scattered cells (less than 1\%). Chromogranin A, OLIG2, IDH1 R132H mutant protein, EMA, pankeratin, p40, p63, CD34, progesterone receptor, HMB45, Melan-A, SOX10, desmin, smooth muscle actin, muscle specific actin, CD10, L1CAM, and WT-1 were negative by immunohistochemistry. INI-1 and ATRX expression were retained. The tumor cells showed strong nuclear p53 and c-Myc expression in most tumor cells and had a high Ki-67 (MIB-1) proliferative index (approximated at 60\%). We classified the tumor as "central nervous system embryonal tumor, not otherwise specified". The tumor was negative for EWSR1 rearrangement by fluorescence in situ hybridization (FISH). Histology of post-chemotherapy re-excision specimens were similar to the original with focal minimal necrosis (in approximately $10 \%$ of the tumor).

Next-generation sequencing (NGS) using the UCSF500 panel was performed (as described in reference [1]), which revealed a novel PARD3B-NUTM1 gene fusion between $P A R D 3 B$ intron 3-4 and NUTM1 intron 1-2 resulting in an in-frame fusion of exons 1-3 of PARD3B and exons $2-8$ of NUTM1. The sequence predicts a fusion protein comprising the $\mathrm{N}$-terminal 132 

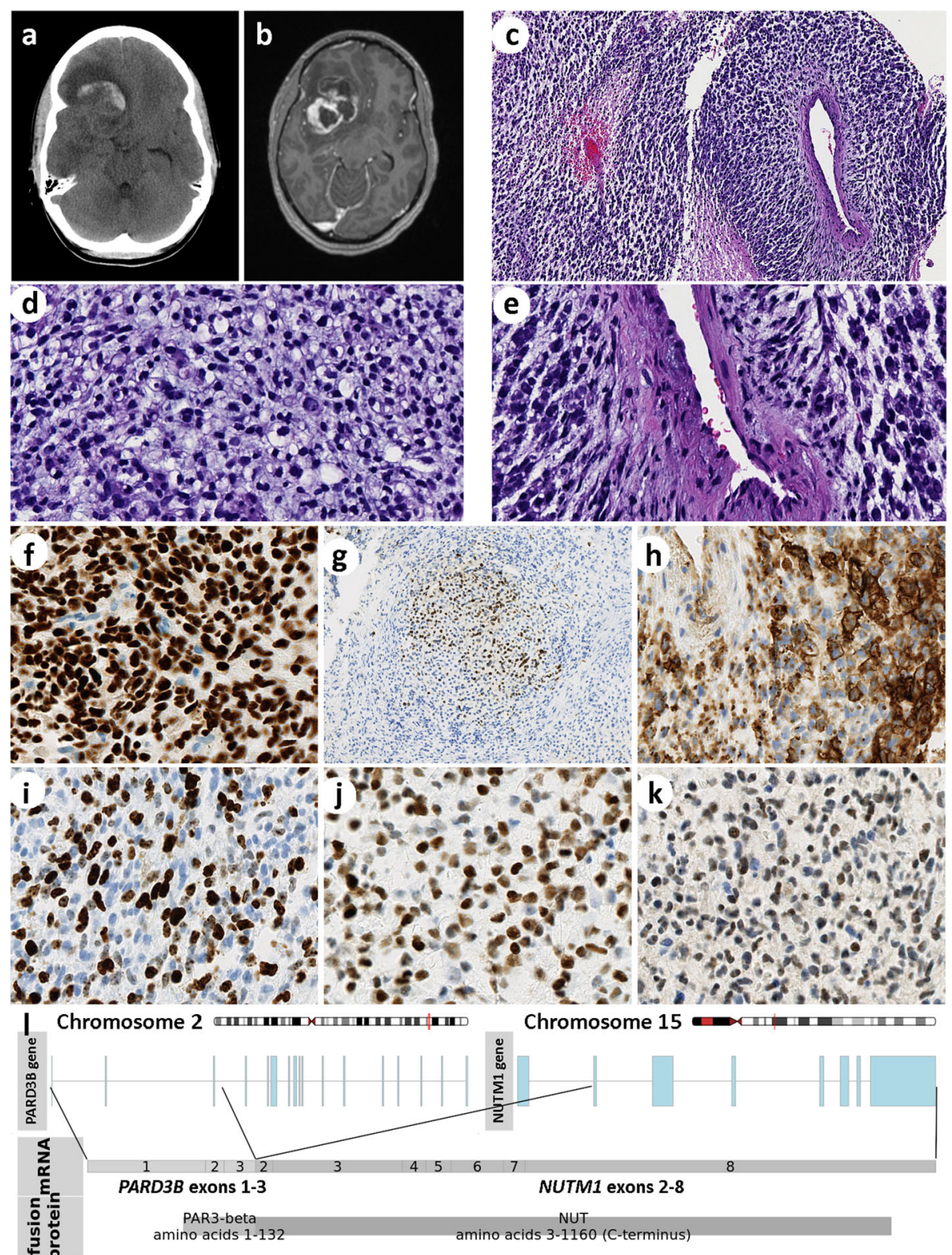

Fig. $1 \mathrm{CT}$ and MRI showed a frontotemporal mass with hemorrhage and surrounding vasogenic edema (a, b). Representative histopathology. Low power view shows variegated appearance (c). Small, primitive-appearing tumor cells with some cytoplasmic clearing and hyperchromatic round-to-oval nuclei (d). Spindle cells with ovoid nuclei and myxoid background condensed around a vessel (e). Diffuse uniform nuclear NUT immunostaining (f). A focus of GFAP expression (g). CD99 stains all tumor cells in a membranous or cytoplasmic dot-like pattern (h). Ki-67 proliferative index is high (i). There is nuclear p53 (j) and c-Myc ( $\mathrm{k}$ ) expression in most tumor cells. PARD3B-NUTM1 gene fusion, discovered by NGS of tumor DNA, predicts a fusion protein (I)

amino acids of the partitioning defective 3 homolog $\mathrm{B}$ protein $($ PAR3- $\beta$ ) and almost the entire NUT protein (amino acids $3-1160 \mathrm{C}$-terminus) (Fig. 1 l). There was also a BRCA2 nonsense mutation (p.K944*, c.1830A > $\mathrm{T})$, which was present at a heterozygous allele frequency. NGS also showed chromosomal copy number changes that included gains of $6 \mathrm{p}$ and interstitial $15 \mathrm{q}$, and loss of 6q. However, NGS did not detect TP53 or MYC alterations including mutation, amplification or rearrangements despite p53 and c-myc protein overexpression. Subsequent immunohistochemistry showed diffuse strong nuclear expression of NUT protein.

\section{Discussion}

NUT carcinoma is an aggressive midline carcinoma predominantly seen in the head and neck region with 
undifferentiated or poorly differentiated morphology characterized by NUT expression [2]. The prognosis of NUT carcinomas is poor, with a median survival of 9.8 months [3]. It is now apparent that NUTM1 gene fusions also characterize a subset of undifferentiated soft tissue and visceral tumors not restricted to carcinomas or to the midline [4] and also has been described in BALL [5] . NUTM1-rearranged tumors often exhibit rapid growth and spread. Histologically they are heterogeneous and sometimes variegated and have a poorly differentiated cytology. In the brain, several NUTM1 rearrangements have been reported (Table 1). Five of the six cases reported as examples of a newly defined entity called "CNS Ewing sarcoma family tumor with CIC alteration" were shown to express NUT protein by immunohistochemistry and two of these were shown to have CIC-NUTM1 fusion [6]. An exceptional case of a NUTM1-rearranged brain tumor resulted in a diseasefree survival at 16 months [7]. Our case showed a very aggressive course in the setting of a novel PARD3BNUTM1 fusion accompanied by chromosomal copy number changes. PAR3-beta, the product of PARD3B, regulates cell-cell contact and indirectly activates the Hippo pathway, but few studies implicate $P A R D 3 B$ in tumorigenesis $[8,9]$.

The clinical and histopathologic features of the NUTM1-rearranged brain tumors reported to date are not specific and pose a diagnostic challenge. For the three cases with available histologic description, the tumors showed young age at presentation and hyperchromatic nuclei $[4,7]$. Cytologic features were dissimilar. A myxoid background component was a common feature. GFAP expression varied from focal to diffuse. The reported cases were consistently negative for cytokeratin and chromogranin $\mathrm{A}$, and at most focally positive for synaptophysin. There was strong nuclear expression of NUT protein expressed in all five cases. In contrast, some soft tissue and visceral NUTM1-rearranged tumors were negative for NUT expression by immunohistochemistry. The reported NUTM1-rearranged brain tumors were not designated as a specific entity. Based on the morphologic features, intra-axial location, lack of other primary site, diffuse CD99 and CD56 and focal GFAP and neurofilament positivity, lack of carcinoma and sarcoma markers, and lack of histologic and molecular alterations that define other specific CNS primitive neuroectodermal tumors, our case was classified as "CNS embryonal tumor, not otherwise classified" category in the current WHO classification system, which is equivalent to CNS primitive neuroectodermal tumor in previous WHO classification systems.

The reported cases of NUTM1-rearrangements in primary brain tumors were discovered by NGS (Table 1). RNA sequencing was performed either retrospectively or for research purposes for cases 1, 2, and 3. RNA sequencing was performed for diagnostic workup in case 4 (ATXN1-NUTM1). In the current case, DNA sequencing

Table 1 Comparison of reported NUTM1-rearranged primary brain tumors

\begin{tabular}{|c|c|c|c|c|c|c|c|}
\hline & $\begin{array}{l}\text { Fusion } \\
\text { gene }\end{array}$ & $\begin{array}{l}\text { Age } \\
\text { Sex } \\
\text { Location }\end{array}$ & Histology & IHC profile & Course & Discovery & Reference \\
\hline $\begin{array}{l}\text { Cases } \\
1 \& 2 \\
*\end{array}$ & $\begin{array}{l}\text { CIC- } \\
\text { NUTM1 } \\
\text { (2 cases) }\end{array}$ & $\begin{array}{l}\text { Not } \\
\text { available }\end{array}$ & $\begin{array}{l}\text { Small-cell phenotype, alveolar and } \\
\text { fascicular growth }\end{array}$ & NUT (strong). & Not available & $\begin{array}{l}\text { RNA sequencing of } \\
\text { select cases }\end{array}$ & 6 \\
\hline $\begin{array}{l}\text { Case } \\
3\end{array}$ & $\begin{array}{l}\text { BRD4- } \\
\text { NUTM1 }\end{array}$ & $\begin{array}{l}3, \\
\text { Male, } \\
\text { Parietal } \\
\text { lobe }\end{array}$ & $\begin{array}{l}\text { Small round cells. Epithelioid- } \\
\text { polygonal cells with a reticular- } \\
\text { alveolar pattern and prominent } \\
\text { myxoid stroma. Nuclear molding, } \\
\text { speckled chromatin and conspicu- } \\
\text { ous mitotic activity. }\end{array}$ & $\begin{array}{l}\text { GFAP (2+, focal), synaptophysin } \\
(1+) \text {, NUT (5+). } \\
\text { Negative: pan-keratin, HMWK, } \\
\text { LMWK, C4, p63, chromogranin }\end{array}$ & $\begin{array}{l}\text { Died of } \\
\text { disease } 12 \\
\text { months post- } \\
\text { op with } \\
\text { chemotherapy }\end{array}$ & $\begin{array}{l}\text { Retrospective RNA } \\
\text { sequencing of } \\
\text { undifferentiated } \\
\text { tumors with nuclear } \\
\text { isomorphism }\end{array}$ & 4 \\
\hline $\begin{array}{l}\text { Case } \\
4\end{array}$ & $\begin{array}{l}\text { ATXN1- } \\
\text { NUTM1 }\end{array}$ & $\begin{array}{l}21, \\
\text { Female, } \\
\text { Frontal } \\
\text { lobe }\end{array}$ & $\begin{array}{l}\text { Fascicular architecture and } \\
\text { chondro-myxoid areas; some } \\
\text { neuron-like tumor cells; large } \\
\text { nucleoli }\end{array}$ & $\begin{array}{l}\text { NUT, GFAP (strong), } \\
\text { p53, CD56, } \\
\text { Negative: OLIG2, S100, TTF1, } \\
\text { chromogranin, synaptophysin, } \\
\text { CD34, p63, CK5/6, SMA. } \\
\text { Wild type: ATRX, INI1, BRG1 }\end{array}$ & $\begin{array}{l}\text { Disease -free } \\
16 \text { months } \\
\text { post-op }\end{array}$ & $\begin{array}{l}\text { RNA sequencing of a } \\
\text { brain tumor after } \\
\text { classification by } \\
\text { methylation profile } \\
\text { and NUT IHC. }\end{array}$ & 7 \\
\hline $\begin{array}{l}\text { Case } \\
5\end{array}$ & $\begin{array}{l}\text { PARD3B- } \\
\text { NUTM1 }\end{array}$ & $\begin{array}{l}\text { 29, } \\
\text { Female, } \\
\text { Frontal } \\
\text { lobe }\end{array}$ & $\begin{array}{l}\text { Variegated tumor consisting mostly } \\
\text { of small epithelioid cells with } \\
\text { myxoid or fibrillar background }\end{array}$ & $\begin{array}{l}\text { NUT, CD99, CD56, p53, GFAP } \\
\text { (focal), neurofilament (focal). } \\
\text { Negative: Keratin, p63, desmin, } \\
\text { S-100, chromogranin A, synapto- } \\
\text { physin (only rare cells positive), } \\
\text { OLIG2, IDH R132H, EMA, SOX10, } \\
\text { actins, } \\
\text { Wild-type: INI-1, ATRX }\end{array}$ & $\begin{array}{l}\text { Died of } \\
\text { disease one } \\
\text { month post- } \\
\text { op }\end{array}$ & $\begin{array}{l}\text { DNA sequencing } \\
\text { panel }\end{array}$ & $\begin{array}{l}\text { Current } \\
\text { case }\end{array}$ \\
\hline
\end{tabular}

*Features of cases 1 and 2 are based on overall description of CNS Ewing sarcoma family tumor with CIC alteration cases reported in reference [6] 
was performed for diagnostic workup, revealing additional chromosomal copy number changes.

To our best knowledge, PARD3B-NUTM1 fusion has not been reported in any tumor. As our case illustrates, utilization of NGS for routine diagnostic workup of primitive appearing CNS tumors may uncover more NUTM1-rearranged tumors with different fusion partners. Molecular analysis of these aggressive tumors may explain the differences seen in histopathologies and provide clues to prognosis and identification of novel therapies.

\section{Abbreviations}

FISH: Fluorescence in-situ hybridization; NGS: Next generation sequencing

\section{Acknowledgements}

Not applicable.

\section{Authors' contributions}

All authors contributed to clinical care of the patient and preparing and reviewing the manuscript.

\section{Funding}

This study was not funded.

\section{Availability of data and materials}

Not applicable.

\section{Ethics approval and consent to participate}

The Georgetown University IRB has reviewed the case and determined that the above case study is exempt from IRB approval.

\section{Consent for publication}

Not applicable.

\section{Competing interests}

The authors declare that there are no competing interests.

\section{Author details}

${ }^{1}$ Department of Pathology and Laboratory Medicine, Georgetown University Hospital, 3900 Reservoir Rd NW, Washington, DC 20007, USA. ²Departments of Oncology and Pediatrics, Georgetown University School of Medicine, 3970 Reservoir Rd NW, Washington, DC 20057, USA. ²Department of Neurology, MedStar Georgetown University Hospital, 3800 Reservoir Rd NW, Washington, DC 20007, USA. ${ }^{4}$ Department of Neurosurgery, MedStar Georgetown University Hospital, 3800 Reservoir Rd NW, Washington, DC 20007, USA ${ }^{5}$ Department of Pathology, University of California, San Francisco, 505 Parnassus Ave, San Francisco, CA 94143, USA

Received: 10 June 2020 Accepted: 8 July 2020

Published online: 17 July 2020

\section{References}

1. Kline CN, Joseph NM, Grenert JP, van Ziffle J, Talevich E, Onodera C et al (2016) Targeted next-generation sequencing of pediatric neuro-oncology patients improves diagnosis, identifies pathogenic germline mutations, and directs targeted therapy. Neuro-Oncology 19:699-709. https://doi.org/10. 1093/neuonc/now254

2. El-Naggar AK, Chan JK, Grandis JR, Takata T, Slootweg PJ (2017) WHO classification of head and neck Tumours, 4th edn. International Agency for Research on Cancer, Lyon

3. Chau NG, Mitchell CM, Aserlind A, Grunfeld N, Kaplan L, Bauer DE et al (2014) Aggressive treatment and survival outcomes in NUT midline carcinoma (NMC) of the head and neck (HN). JCO. 32:6057. https://doi.org/ 10.1200/jco.2014.32.15_suppl.6057

4. Dickson BC, Sung Y, Rosenblum MK, Reuter VE, Harb M, Wunder JS et al (2018) NUTM1 gene fusions characterize a subset of undifferentiated soft tissue and visceral tumors. Am J Surg Pathol 42:636-645. https://doi.org/10. 1097/PAS.0000000000001021

5. Li J, Dai Y, Lilljebjörn H, Shen S, Cui B, Bai L et al (2018) Transcriptional landscape of B cell precursor acute lymphoblastic leukemia based on an international study of 1,223 cases. Proc Natl Acad Sci U S A 115:E11711E11720. https://doi.org/10.1073/pnas.1814397115

6. Sturm D, Orr B, Toprak U, Hovestadt V, Jones DW, Capper D et al (2016) New brain tumor entities emerge from molecular classification of CNSPNETs. Cell. 164:1060-1072. https://doi.org/10.1016/j.cell.2016.01.015

7. Siegfried A, Masliah-Planchon J, Roux F, Larrieu-Ciron D, Pierron G, Nicaise $Y$ et al (2019) Brain tumor with an ATXN1-NUTM1 fusion gene expands the histologic spectrum of NUTM1-rearranged neoplasia. Acta neuropathologica communications 7:220. https://doi.org/10.1186/s40478-019-0870-8

8. Bonastre E, Verdura S, Zondervan I, Facchinetti F, Lantuejoul S, Chiara MD, et al. PARD3 Inactivation in Lung Squamous Cell Carcinomas Impairs STAT3 and Promotes Malignant Invasion. Cancer Res. 2015;75: 1287-1297. doi: https://doi.org/10.1158/0008-5472.CAN-14-2444 [doi]

9. Milano DF, Ngai NA, Muthuswamy SK, Asthagiri AR (2016) Regulators of metastasis modulate the migratory response to cell contact under spatial confinement. Biophys J 110:1886-1895 doi: S0006-3495(16)30113-8 [pii]

\section{Publisher's Note}

Springer Nature remains neutral with regard to jurisdictional claims in published maps and institutional affiliations.

\section{Ready to submit your research? Choose BMC and benefit from:}

- fast, convenient online submission

- thorough peer review by experienced researchers in your field

- rapid publication on acceptance

- support for research data, including large and complex data types

- gold Open Access which fosters wider collaboration and increased citations

- maximum visibility for your research: over $100 \mathrm{M}$ website views per year

At $\mathrm{BMC}$, research is always in progress.

Learn more biomedcentral.com/submissions 